\title{
NONLINEAR RETARDED INTEGRAL INEQUALITIES ON TIME SCALES AND THEIR APPLICATIONS
}

\author{
Haidong LiU And FAnWei Meng
}

\begin{abstract}
In this paper, some new nonlinear retarded integral inequalities on time scales are established, which provide a handy tool in the study of some retarded integral equations and dynamic equations on time scales. The results unify and extend some continuous inequalities and their corresponding discrete analogues. Some applications are also presented to illustrate the usefulness of some of our results.
\end{abstract}

Mathematics subject classification (2010): 26D15, 26E70, 34A40, 39A12.

Keywords and phrases: Retarded integral inequality, time scales, dynamic equation, bounds.

\section{REFERENCES}

[1] M. AdIVAR, AND Y. N. RAFFOUL, Existence results for periodic solutions of integro-dynamic equations on time scales, Ann. Mat. Pura Appl 188, 4 (2009), 543-559.

[2] R. Agarwal, M. Bohner And A. Peterson, Inequalities on time scales: a survey, Math. Inequal. Appl 4, 4 (2001), 535-557.

[3] D. R. Anderson, Nonlinear dynamic integral inequalities in two independent variables on time scale pairs, Adv. Dyn. Syst. Appl 3, 1 (2008), 1-13.

[4] F. M. Atici, D. C. Biles And A. Lebedinsky, An application of time scales to economics, Math. Comput. Modelling 43, 7 (2006), 718-726.

[5] L. BI, M. Bohner AND M. FAN, Periodic solutions of functional dynamic equations with infinite delay, Nonlinear Anal 68, 5 (2008), 170-174.

[6] M. Bohner And A. Peterson, Dynamic Equations on Time Scales: An Introduction with Applications, Birkhäuser, Boston, Mass, 2001.

[7] M. Bohner And A. Peterson (eds.), Advances in Dynamic Equations on Time Scales, Birkhäuser, Boston, Mass, 2003.

[8] F. B. Christiansen And T. M. Fenchel, Theories of Populations in Biological Communities, Lectures Notes in Ecological Studies, Springer-Verlag, 1977.

[9] A. Dogan, J. GRAeF AND L. Kong, Higher-order singular multi-point boundary-value problems on time scales, Proc. Edinb. Math. Soc 54, 2 (2011), 345-361.

[10] L. ERbe, B. G. JiA AND A. Peterson, Belohorec-type oscillation theorem for second order sublinear dynamic equations on time scales, Math. Nachr 284, 13 (2011), 1658-1668.

[11] L. ERBe, B. G. JiA AND A. Peterson, On the asymptotic behavior of solutions of EmdenCFowler equations on time scales, Ann. Mat. Pura Appl 191, 2 (2012), 205-217.

[12] M. Federson, J. G. Mesquita And A. Slavík, Measure functional differential equations and functional dynamic equations on time scales, J. Diff. Equations 252, 6 (2012), 3816-3847.

[13] Q. H. FEnG AND B. ZHENG, Generalized Gronwall-Bellman-type delay dynamic inequalities on time scales and their applications, Appl. Math. Comput 218, 15 (2012), 7880-7892.

[14] Q. H. Feng, F. W. Meng, Y. M. Zhang, J. C. Zhou and B. Zheng, Some delay integral inequalities on time scales and their applications in the theory of dynamic equations, Abstr. Appl. Anal 2012, 1 (2012), Article ID 538247.

[15] Q. H. Feng, F. W. Meng And B. Zheng, Gronwall-Bellman type nonlinear delay integral inequalities on time scale, J. Math. Anal. Appl 382, 2 (2011), 772-784. 
[16] J. Gu And F. W. Meng, Some new nonlinear Volterra-Fredholm type dynamic integral inequalities on time scales, Appl. Math. Comput 245, 1 (2014), 235-242.

[17] S. HILGER, Analysis on measure chains-a unified approach to continuous and discrete calculus, Results. Math 18, 1 (1990), 18-56.

[18] S. KelLER, Asymptotisches Verhalten invarianter Faserbündel bei Diskretisierung und Mittelwertbildung in Rahmen der Analysis auf Zeitskalin, PhD thesis, Universität Augsburg, 1999.

[19] W. N. LI, Some delay integral inequalities on time scales, Comput. Math. Appl 59, 6 (2010), 19291936.

[20] O. Lipovan, A retarded integral inequality and its applications, J. Math. Anal. Appl 285, 2 (2003), 436-443.

[21] Q. H. MA AND J. PEČARIĆ, The bounds on the solutions of certain two-dimensional delay dynamic systems on time scales, Comput. Math. Appl 61, 61 (2011), 2158-2163.

[22] Q. H. MA, J. W. WANG, X. H. KE AND J. PEČARIĆ, On the boundedness of a class of nonlinear dynamic equations of second order, Appl. Math. Lett 26, 11 (2013), 1099-1105.

[23] F. W. Meng And J. ShaO, Some new Volterra-Fredholm type dynamic integral inequalities on time scales, Appl. Math. Comput 223, 1 (2013), 444-451.

[24] B. G. PACHPATTE, On some new inequalities related to certain inequalities in the theory of differential equations, J. Math. Anal. Appl 189, 1 (1995), 128-144.

[25] D. B. PachpatTe, Explicit estimates on integral inequalities with time scale, J. Inequal. Pure Appl. Math 7, 4 (2006), Article 143.

[26] S. H. SAKER, Some nonlinear dynamic inequalities on time scales, Math. Inequal. Appl 14, 3 (2011), 633-645.

[27] S. H. SAKER, Some nonlinear dynamic inequalities on time scales and applications, J. Math. Inequal 4, 4 (2010), 561-579.

[28] A. SLavíK, Averaging dynamic equations on time scales, J. Math. Anal. Appl 388, 2 (2012), 9961012.

[29] Y. G. Sun, On retarded integral inequalities and their applications, J. Math. Anal. Appl 301, 301 (2005), 265-275.

[30] Y. G. Sun, Some sublinear dynamic integral inequalities on time scales, Math. Inequal. Appl 15, 2 (2012), 331-341.

[31] Y. G. SUn AND T. HASSAN, Some nonlinear dynamic integral inequalities on time scales, Appl. Math. Comput 220, 4 (2013), 221-225.

[32] L. YIN, Q. LUO, AND F. QI, Several integral inequalities on time scales, J. Math. Inequal 6, 3 (2012), 419-429. 